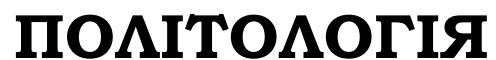

DOI https://doi.org/10.32782/2305-9389/2020.23.15

УДК 323.1:141

Бондар Ярослав, здобувач наукового ступеня кандидата політичних наук Ніжинського державного університету імені Миколи Гоголя

\section{ПЕРСПЕКТИВИ УКРАЇНСЬКОЇ НАЦІОНАЛЬНО-ВИЗВОЛЬНОЇ БОРОТЬБИ В ПОЛІТИЧНІЙ ДУМЦІ ДІЯЧІВ МЕЛЬНИКІВСЬКОГО СЕРЕДОВИЩА}

\begin{abstract}
У статті здійснено вивчення змісту творчої спадщини діячів мельниківського середовища за період початку 1950-х - кінияя 1960-х рр. (3. Книта (член ОУН(м), обіймав різні посади в ОУН)), Д. Андрієвського (член ОУН(м)), О. Бойдуника (член ПУН(м)), Я. Гайваса (член ОУН(м)). Дослідження показало, щзо хихнє бачення засад української революиії та подальшого державотворення має поміркований, ліберальний, консервативно-конструктивний характер. Доведено, щзо у своїх історичних, політичних, геополітичних творах иі автори порушують важливі проблеми розвитку українського визвольного руху, демонструють актуальну потребу завчасного створення програмних засад розвитку незалежної, самостійної, соборної України. Визначено, щчо їхні підходи вирізняються критичністю, раціоналізмом, вони об'єктивно оцінюють важсливий недолік украӥнського визвольного руху, пов'язаний із відсутністю єдності в здійсненні звільнення від імперського російського впливу. Встановлено, щчо найбільш раціональні підходи представлено в прачях 3. Книша, який, на відміну від бандерівського крила українських націоналістів, які дотримувались ірраціоналістичних підходів, оцінював участь українського визвольного руху в боротьбі проти більшовиків із позииій доиільності. Показано, щчо автор вважав, щзо до початку реальних військових подій проти СРСР потрібно вести підготовчу фазу боротьби, готувати український народ до спротиву і вступати у війну з підготовленими силами, щяоб краӥни Заходу всерйоз сприймали Україну як рівноправного прихильника у військовому конфлікті. Виявлено, щзо в працях Д. Андрівського подана об'єктивна оиінка міжнародної ситуачіï періоду 1955-1965 рр., на особливу увагу заслуговують сформовані автором характеристики геополітичної картини світу. Зазначається, щзо О. Бойдуник вагому увагу приділяє подоланню внутрішніх ідеологічних, організачійних проблем у середовищі украйнських начіоналістів, доводить потребу покращення партнерства із Заходом. Доведено, щзо Я. Гайвас присвятив значну увагу розвитку Україною відносин на міжнародній арені. У більшості з ции дослідників, як і у представників бандерівського крила, важливе місче у творчості посідає проблема боротьби з проявами імперського російського впливу та окупачією України. Ця проблема залишається актуальною для України, як і багатьох краӥн колишнього СРСР $і$ в XXI cm.
\end{abstract}

Ключові слова: мельниківське середовище, геополітична картина світу, украӥнська начіонально-визвольна боротьба, українські націоналісти, російський вплив, окупація.

\section{Bondar Yaroslav. Prospects of the Ukrainian national liberation struggle in the political thought of Melnyk activists}

The article examines the content of the creative heritage of Melnyk activists during the early 1950s - late 1960s (Z. Knysha (member of the OUN (m), held various positions in the OUN)), D. Andrievsky (member of the OUN $(m)$ ), O. Boydunik (member of PUN $(m)$ ), J. Gaivas (member of OUN $(m)$ ). The study showed that their vision of the foundations of the Ukrainian revolution and subsequent state formation is moderate, liberal, conservative and constructive. It is proved that in their historical, political, geopolitical works these authors raise important issues of development of the Ukrainian liberation movement, demonstrate the urgent need for early creation of program principles of development of independent, sovereign, united Ukraine. It is determined that their approaches are critical, rational, they objectively assess the important shortcoming of the Ukrainian liberation movement due to the lack of unity in the implementation of liberation from imperial Russian influence. It is established that the most rational approaches are presented in the works of Z. Knysh, who, in contrast to the Bandera wing of Ukrainian nationalists, who followed irrationalist approaches, assessed the participation of the Ukrainian liberation movement in the struggle against the Bolsheviks from the standpoint of expediency. It is shown that the author believed that before the real military events against the USSR it was necessary to conduct a preparatory phase of struggle, prepare the Ukrainian people for resistance and go to war with trained forces, so that Western countries take Ukraine seriously as an equal supporter in military conflict. It is revealed that in the works of D. Andrivsky an objective assessment of the international situation of the period 1955-1965 is given, the characteristics of the geopolitical picture of the world formed by the author deserve special attention. It is noted that $O$. Boydunyk pays great attention to overcoming internal ideological and organizational problems among Ukrainian nationalists, proves the need to improve the partnership with the West. It is proved that Gaivas paid considerable attention to the development of Ukraine's relations in the international arena. In most of these researchers, as well as in the representatives of the Bandera wing, 
an important place in his work is occupied by the problem of combating the manifestations of imperial Russian influence and the occupation of Ukraine. This problem remains relevant for Ukraine, as well as many countries of the former USSR in the XXI century.

Key words: Melnyk environment, geopolitical picture of the world, Ukrainian national liberation struggle, Ukrainian nationalists, Russian influence, occupation.

Важливий внесок у розвиток українського визвольного руху здійснили представники однієї з течій Організації українських націоналістів, а саме діячі ОУН(м), яких у наукових, історичних, публіцистичних працях називають «мельниківцями», учасниками мельниківського середовища. Ідеологи цієї течії залишили широкий масив теоретичних напрацювань, присвячених історії українського націоналізму, питанням ведення української визвольної боротьби. Дослідження їхніх історичних нарисів, ідеологічної спадщини важливе для розуміння картини розвитку цього процесу відповідно до підходів цих діячів.

Нами будуть проаналізовані положення творів діячів мельниківського середовища, які здійснили найбільший теоретичний внесок у розвиток основних підходів до проблеми української визвольної боротьби в період із початку 1950-хх рр. до кінця 1960-х рр.: висвітлено основні підходи 3. Книша (член ОУН(м), обіймав різні посади в ОУН), Д. Андрієвського (член ОУН(м)), О. Бойдуника (член ПУН(м), Я. Гайваса (член ОУН(м)).

Визначимо основні засади української визвольної боротьби, окреслені в працях 3. Книша.

Питання перспектив початку та розвитку Третьої світової війни між так званим «Сходом» в особі СРСР, його сателітів та «Заходом» 3. Книш висвітлює у творі «За смілий погляд на дійсність» [1]. Зазначена праця була написана в 1950 р., коли світ відновлювався від наслідків Другої світової війни. Автор вказує, що більшовики в ті часи вважали, що мають перевагу у підготовці до війни, оскільки СРСР розвивається в напрямі будівництва всіх галузей, в тому числі військової, а країни Заходу стоять на межі економічної кризи, що не сприятиме швидкій перемозі у військових подіях [1, с. 26]. Важливим напрямом ідеології 3. Книша був раціональний підхід до розуміння основних засад ведення української визвольної боротьби: автор виступає проти масового партизанського руху в поневоленій Україні, аргументуючи це тим, що непідготовлені люди стануть передчасними жертвами більшовиків. При цьому він виступав за використання добре підготовлених невеликих груп, які займатимуться підготовкою населення до боротьби, проводитимуть ідеологічну роботу серед українського народу щодо повстання проти СРСР у разі початку війни [1, с. 37-38]. 3. Книш відстоював позиції раціоналістичного погляду на ведення боротьби, він чітко аргументував це необхідністю збереження нації, тим, що кілька тисяч підготовлених військових будуть більш корисними для перемоги, аніж мільйони цивільних українців, які героїчно загинуть, але будуть втрачені для країни [1, с. 39]. Можемо констатувати, що 3. Книш, на відміну від бандерівського крила українських націоналістів, які дотримувались ірраціоналістичних підходів, оцінював участь українського визвольного руху у боротьбі проти більшовиків із позицій доцільності. Він вважав, що до початку реальних військових подій проти СРСР потрібно вести підготовчу фазу боротьби, готувати український народ до спротиву і вступати у війну з підготовленими силами, щоб країни Заходу всерйоз сприймали Україну як рівноправного прихильника у військовому конфлікті [1, с. 39-40].

У статті «Що буде завтра?» (1950р.) [2] 3. Книш розвиває питання нової ролі та місця України в нових геополітичних умовах, пов'язаних із поразкою СРСР у Третій світовій війні. Автор скептично оцінює перспективу того, що світова спільнота схвально та позитивно прийме позиції УНРради щодо можливості самовизначення України при розвалі СРСР. Дослідник вказує, що країни Заходу не схильні розглядати народи СРСР як окремі нації, вони, за твердженням автора, зазвичай розглядають їх у межах російської національної групи [2, с. 62]. 3. Книш зазначає, що Захід має визнати існування української нації, для цього потрібна висока організація всіх українських націоналістів, підготовка українського народу, визнання УНРради всією країною. Автор доводить, що такі позиції слід визначати ще перед початком нової глобальної війни, оскільки потім українці не зможуть вибрати шлях до самовизначення [2, с. 60-62]. Автор наголошує на тому, що для майбутньої незалежності України в умовах можливої поразки СРСР потрібне масштабне об'єднання українських націоналістів-емігрантів на єдиних позиціях, об'єднання УНРради з українським народом шляхом налагодження постійного діалогу та підтримки.

У статті «До проблем тривожного майбутнього» [3] (1950р.) 3. Книш аналізує важливу соціальнодемографічну проблему України, зокрема зростання частки населення російської національності в складі загального населення УРСР. Автор вказує, що цей аспект є важливою внутрішньою загрозою для України після отримання незалежності, впливатиме на появу конфліктів, порушення внутрішнього 
порядку через національні, мовні, культурні питання [3, с. 16-22]. Дослідник зазначає, що це питання може бути вирішене тільки радикальним методом, зокрема, за допомогою закріплення на державному рівні заходу з переселення російської меншості з території України [3, с. 19]. 3. Книш звертає увагу на те, що ця акція в державотворенні України буде складною через масове штучне переселення росіян, особливо після подій Голодомору і асиміляцію їх серед місцевих. Як свідчить історія, найбільшою мірою це стосувалось сходу України. Автор грунтовно доводить, що це питання потрібно розробляти і мати комплексний підхід до організованого процесу депортації росіян, оскільки від ефективності цього заходу буде залежати безпека країни. Нині в українських реаліях такий підхід може вважатися дуже радикальним і таким, що не відповідає реальним правовим, політичним, соціальним умовам державотворення. Але питання впливу російського питання на функціонування країни, особливо в нинішніх умовах російсько-українського конфлікту, стало дуже гострим для України. Відповідно, можемо констатувати об’єктивність автора в акцентуванні на цій проблемі і зазначенні необхідності їі вирішення в інтересах українського народу.

Вивчення змісту статті 3. Книша «Без ілюзій» (1957р.) [4] показує, що автор критично оцінює ставлення країн Заходу та США до національних визвольних рухів у світі проти СРСР, у тому числі українського. Дослідник об'єктивно репрезентує події Угорської революції (1956 р.), повстання робітників у Східній Німеччині (1953р.), польські повстання різних періодів, події у Фінляндії (1939р.), інші революційні ситуації, коли країни Заходу та США обмежувались тільки засудженням радянського втручання у внутрішню політику інших країн, але не були націлені переходити до стадії військової інтервенції на захист повстанців із національних рухів [4, с. 7]. Автор висвітлює трансформації американської доктрини зовнішньої політики щодо СРСР. Дослідження положень цієї доктрини показує, що США змінювали свої відносини з Радянським Союзом з 1917 р. по 1957 р. із політики так званого «заспокоювання» до «стримування» та холодної війни, яка також була націлена на стримування імперського ворога від відкритої військової агресії, переважно проти Західного світу [4, с.7]. За твердженням 3. Книша, країни Заходу ще меншою мірою, аніж США, націлені втручатися у внутрішні справи народів СРСР, інших країн, які не входили до складу Радянського Союзу. Також можна підтримати зауваження автора, що країни Заходу та США проявляють значний осуд дій російської сторони, коли вона намагається впливати на внутрішні справи вільних країн, що не є республіками СРСР, але не хочуть псувати відносини з Москвою через внутрішні національні проблеми народів Радянського Союзу. 3. Книш не вдається до звинувачень такої зовнішньої політики Заходу, але справедливо констатує, що українська визвольна політика має виходити з означених геополітичних позицій.

Праця Д. Андрівського «Перспективи укладу світових сил та українська міжнародна акція» присвячена висвітленню геополітичної ситуації навколо протистояння двох наддержав (СРСР та США), зовнішньої політики країн Заходу щодо російської імперської гегемонії у світі, зовнішніх позицій країнсателітів Радянського Союзу, країн, що не визначились із підтримкою комуністичного або так званого «вільного світу», перспектив розвитку української міжнародної політики [5]. Ця стаття була написана автором у часовому інтервалі 1955-1965 pp. Д. Андрівський об’єктивно оцінює міжнародну ситуацію того часу, на особливу увагу заслуговують такі характеристики геополітичної картини світу в рамках 1955-1965 рр., визначеної автором у творі [5, с. 2-6, 12]:

- існування двох наддержав (США та СРСР) із країнами, що підтримують кожну з них, виходячи 3 власних історичних, політичних традицій. Автор наводить комплексну статистику розподілу сил кожного з таборів, зауважуючи, що хоча вона і приблизна, але достатньо грунтовно та системно визначає вказане питання. Ця статистика виглядає так: 1) США та НАТО підтримують 15 країн Заходу (430 млн населення), 7 держав Сходу з Тихоокеанського блоку (167 млн населення), 7 країн Південно-східного Блоку (380 млн населення); 2) СРСР та 8 країн-сателітів (із загальною кількістю 305 млн населення), радянську політику підтримують також держави-сателіти на Сході - 3 країни (630 млн населення). Окрім країн, що чітко визначилися з підтримкою, за твердженням автора, $є$ так звані «нейтральні» території (країни Європи, Азії, країни Арабської ліги тощо). У рамках цього розподілу світу дослідник вказує на те, що СРСР у разі початку Третьої світової війни матиме суттєву перевагу за наземними операціями, а країни Заходу будуть переважати за рівнем та кількістю техніки, авіацією, економічною потужністю;

- ставлення країн Заходу до зовнішньої політики СРСР є суперечливими, відсутня єдина платформа сприйняття Радянського Союзу як ворога. Це, за твердженням автора, може підштовхнути США змінити стратегію, орієнтовану на підтримку західними країнами, на стратегію, націлену на підтримку Англією, Іспанією, Північною Африкою. Дослідник визначає, що коливання та непорозуміння країн Заходу в їхньому ставленні до СРСР у зазначений період є сприятливим для росіян; 
- зростання підтримки СРСР на території країн Сходу (Індокитаю, Індонезії, країнах Азії та Африки) сприяє загальному розширенню впливу російських імперських інтересів;

- поява так званих «третіх таборів», представлених країнами, що не визначилися з підтримкою комуністів або країн Заходу (країни групи Коломбо, які до певного періоду були колоніями країн Заходу, Югославія в Свропі). Автор зауважує, що території цих країн можуть в майбутньому стати центрами міжнародного протистояння. Можемо зазначити далекоглядність його тверджень, особливо стосовно Югославії (початок Югославських війн із 1991 р.);

- загроза використання атомної зброї, на думку автора, $є$ одним із факторів стримування початку відкритого військового протистояння між двома потужними світовими акторами;

- 3 СРСР можна вести перемовини тільки «з позицій сили». Це підтверджується тим, що після вступу Німеччини до НАТО Радянський Союз, відчуваючи зростання зовнішньої загрози, почав більш активно брати участь у міжнародних контактах щодо низки питань;

- незважаючи на послаблення терору щодо поневолених народів у складі СРСР, Радянський Союз не залишає свій імперський курс. Хоча, на думку автора, є тенденції до послаблення тоталітаризму в рамках імперії щодо українського та інших народів.

Констатуючи вказані ознаки та характеристики геополітичної картини світу 1955-1965 pp., Д. Андрієвський наголошує на тому, що українським націоналістам, окрім революційної роботи, потрібно здійснювати пропаганду на міжнародному рівні, знаходити підтримку українського визвольного руху за межами України [5, с. 15]. Це, на нашу думку, цілком справедливе твердження, оскільки визнання Заходом права українського народу на незалежну, самостійну державу привернуло б увагу до національного питання, не давало б змоги розглядати СРСР тільки як країну з більшовицьким курсом, але й вказувало б на те, що Радянський Союз $є$ штучним, примусовим утворенням різних народів та етнічних груп.

Доповідь «Що діється в Україні» [6], представлена Д. Андрівським наприкінці 1962 р. перед українцями Великої Британії та Франції, є своєрідним продовженням попереднього твору «Перспективи укладу світових сил та українська міжнародна акція». Автор виклав об'єктивну характеристику подій в Україні з часів усунення сталінського режиму, розвитку так званого явища «хрущовська відлига» (з середини 1950 - до середини 1960 рр.). Дослідник визначає ключові зміни у всіх сферах життя в УРСР за часів правління М. Хрущова. На особливу увагу заслуговує акцент на тому, що програмні засади політики М. Хрущова щодо національних визвольних рухів будувались на засадах імперського курсу, а саме: СРСР декларував підтримку поневолених колоніальних народів (стосується країни Азії, Африки), на територіях яких можна було просувати власні інтереси, і визначав курс на «злиття націй» для народів, об'єднаних у складі Радянського Союзу [6, с. 2-6]. Незважаючи на те, що ця доповідь готувалась автором за часів певної лібералізації, демократизації в СРСР, в її прикінцевих положеннях зазначається, що в 1960-і pр. ще не можна говорити про те, що радянська система близька до розпаду. I, з огляду на це, автор закликає українську еміграцію до єдності в питанні створення спільного національного фронту. Дослідник звертає увагу, що в українських націоналістів відсутні чіткі цілі щодо визволення України і це є одним із вирішальних моментів непорозуміння з країнами Заходу, відсутнє реальне сприяння, окрім певних декларацій.

О. Бойдуник у положеннях своєї доповіді «Сучасний стан визвольної політики» визначає ідеологічні засади визвольної боротьби українських націоналістів. Серед них автором виділено [7, с. 4]:

- отримання суверенності УСДдержавою;

- досягнення суверенності може бути реалізоване власними національними силами. О. Бойдуник акцентує на тому, що створити незалежну, суверенну Україну потрібно саме власними силами, тому тільки різні інші сторони, навіть прихильники визвольної боротьби не стануть цього роботи замість українців. При цьому автор вказує, що перед українським визвольним рухом не стоїть мета відмовлятись від допомоги, особливо військової, але це сприяння не має суперечити національним інтересам. Бачимо, що представники мельниківського середовища, і серед них О. Бойдуник, більш лояльні до співпраці з країнами Заходу в перемозі над СРСР. Не можна стверджувати, що вони декларують безоглядні надії на прихильників, але керуються, на відміну від бандерівського крила українських націоналістів, раціональним прагматизмом у своїй боротьбі. На користь їхнього підходу говорить те, що в часи написання цієї доповіді, в 1965 р. СРСР було відновлено після війни більшість галузей промисловості, в тому числі військову. І хоча військова техніка не була інноваційною, як і більшість продукції інших галузей промисловості, вона мала масштабні розміри. Відповідно, в той період військовий виступ проти такої сили міг мати місце для українського визвольного руху тільки як складовий елемент ворожого до СРСР табору країн Заходу. 
Керуючись цими засадами, автор виділяе дві мети української визвольної боротьби, зокрема: мобілізація всіх українських самостійницьких рухів та сил, яка допоможе в досягненні загальної цілі щодо отримання незалежності країни, забезпечить порозуміння і сприятиме отриманню зовнішньої допомоги; переконання всіх учасників так званого «позабільшовицького світу» в тому, що розвиток російської, більшовицької ідеології у світі згубно вплине на західну культуру, традиції, може змінити цивілізації тощо [7, с. 5]. Можемо констатувати, що у змісті визначення вимог української визвольної боротьби О. Бойдуник також демонструє, що учасники мельниківського націоналістичного середовища великою мірою покладались на допомогу та залучення до процесу визволення України партнерів із Західного табору. У зазначеній доповіді автор вказує на низку внутрішніх проблем у колі українських націоналістів, які потрібно вирішити для створення єдиного центру керування [7, с. 8-11].

Заслуговує на увагу підхід О. Бойдуника до радикального неприйняття співпраці з російським народом, представниками російської еміграції в процесі української визвольної боротьби. О. Бойдуник розрізняє взаємовідносини з росіянами на стадії визвольної боротьби та за умов існування незалежної України.

У статті О. Бойдуника «В поклоні світлому минулому - змагаймо до перемоги в майбутньому» (1965р.) здійснено історіографію національно-визвольних самостійних заходів українського народу. Автор зазначає, що ці заходи не припинялись ніколи, навіть коли СРСР позбавив Україну суверенності та поневолив український народ [8, с. 3]. Дослідник вказує на те, що радянський режим лише формально називає УРСР державою, але насправді це утворення не може вважатися такою. О. Бойдуник зазначає, що УРСР не є державою, оскільки не має власного війська, дипломатичних представництв, власної валюти [8, с. 4]. Автор звертає увагу на необхідність врахування не тільки політичної, історичної, культурної спадщини України, але й на потребу дослідження сучасності, майбутнього. Представлений грунтовний історичний екскурс розвитку українського визвольного руху свідчить про вагомий внесок автора в розвиток вказаного питання. Основний висновок, що можна зробити з тексту досліджуваного твору, є таким: Україна як держава продовжує існувати, і про це треба постійно нагадувати світовій спільноті, акцентуючи на українському визвольному русі, орієнтованому не тільки на повалення комуно-більшовицького режиму, але і на звільнення українського народу від російського імперського режиму [8, с. 5].

Питання майбутніх перспектив визвольної боротьби, певних аспектів розвитку українського державотворення висвітлено Я. Гайвасом у статті «Перспективи української визвольної боротьби і роля української спільноти в світі» (1963 р.) [9]. Автор вказує на те, що всі революційні визвольні рухи, що відбуваються у світі, підтримуються українськими націоналістами, оскільки більшість із них перекликається з прагненнями українського народу позбутися імперського поневолення [9, с. 41-42].

Я. Гайвас, на відміну від розглянутих вище українських націоналістів, як бандерівського, так і мельниківського середовища, визначає не два (продовження холодної війни на подальший період та початок відкритого військового протистояння, яке викличе Третю світову війну), а три варіанти розвитку відносин на міжнародній арені. Зокрема, третім автор виділяє напрям нормалізації відносин між США та СРСР. Дослідник із великим сумнівом ставиться до початку відкритого військового протистояння між двома наддержавами, зауважуючи, що в разі його початку український народ зазнає страшних втрат з огляду на перспективи використання з боку обох сторін новітньої ядерної зброї, здатної знищувати мільйони життів [9, с. 44, 47].

Потрібно зазначити, що на особливу увагу заслуговує підхід Я. Гайваса до побудови соціально-економічних відносин у незалежній Україні: автор вказує на неприйнятність використання тільки приватної власності, яка встановлює домінування над громадянами, і цього не допустить український націоналізм. За твердженням Я. Гайваса, в умовах незалежної України разом із приватною власністю буде впроваджено державну, кооперативну, громадську, муніципальну [9, с. 47]. Цей підхід дещо відрізняється до декларування структури власності в Україні в поглядах українських націоналістів бандерівського крила. Так, Я. Стецько наголошував на перспективах впровадження нового соціального устрою, побудованого на трудовій власності, яка буде включати індивідуальну, індивідуально-родинну, загальну складові частини. Тобто можна припустити, що під загальною Я. Стецько мав на увазі державну власність, під індивідуальною - приватну, а під індивідуально-родинною - власність родини. Отже, Я. Гайвас, керуючись більш комплексним підходом до державотворення, досвідом західних країн скандинавського типу, виступає за виділення в державі типів власності залежно від характеру та типу управління на різних рівнях. Також автор наголошує на необхідності соціального забезпечення в найбільш актуальних сферах, зокрема, сфера навчання та освіти, охорони здоров'я тощо [9, с. 47]. У зазначеній статті дослідник вагому увагу приділяє визначенню подальших кроків українського національного руху за 
різних умов розвитку міжнародних подій, окрім цього, визначає потреу встановлення постійного зворотного зв'язку з українцями на території УРСР [9, с. 49-51]. Я. Гайвас доходить висновку, що в цих умовах потрібно відмовитись від старих методів та способів організації підпілля. Автор вказує, що для уникнення масових арештів більшовиками потрібно замість груп використовувати окремих емісарів, які б індивідуально вели підпільну роботу в країні, жили звичайним життям, але критично оцінювали ситуацію в Україні, завжди були готові до революційних дій [9, с. 53]. Такий підхід показує, що учасники мельниківського руху мали чітку позицію щодо доцільності використання людського потенціалу, закликали до уникнення людських втрат серед українців.

У творі Я. Гайваса «На порозі нового» [10] представлено системний підхід до розуміння штучності більшовицького, імперського курсу СРСР як всередині Радянського Союзу, так і на територіях країнсателітів. Я. Гайвас здійснює масштабну оцінку діяльності російських опозиційних діячів культури, літератури, науки, він вказує на те, що процеси протистояння більшовицькій, партійній, поліцейській владі набувають дедалі більшого поширення в СРСР, УРСР. Заслуговує на підтримку твердження автора про те, що всі ліберальні процеси, які відбуваються в Росії, переважно можуть бути націлені на повалення більшовицького режиму, а не на розпад імперії. Це, на думку автора, підтверджується історією, коли В. Ленін, поваливши царську владу, зберіг імперію [10, с. 5-6]. Слід зазначити справедливість тверджень Я. Гайваса і щодо нинішньої ситуації, коли Росія намагається, використовуючи військову, інформаційну силу, утримувати в полі свого впливу як Україну, так і інші країни, які були раніше поневолені СРСР. І ліберальні та опозиційні рухи, які формально існують у РФ, не протестують проти втручання їх країни у внутрішні справи інших держав.

Вивчення змісту творчої спадщини діячів мельниківського середовища за період початку 1950-х кінця 1960-х рр. показало, що їхне бачення засад української революції та подальшого державотворення має поміркований, ліберальний, консервативно-конструктивний характер. У своїх історичних, політичних, геополітичних творах ці автори порушують важливі проблеми розвитку українського визвольного руху, демонструють актуальну потребу завчасного створення програмних засад розвитку незалежної, самостійної, соборної України. Їхні підходи вирізняються критичністю, раціоналізмом, вони об' єктивно оцінюють важливий недолік українського визвольного руху, пов'язаний із відсутністю єдності у здійсненні звільнення від імперського російського впливу. У більшості з цих дослідників, як і у представників бандерівського крила, важливе місце в творчості посідає проблема боротьби з проявами імперського російського впливу та окупацією України. Ця проблема залишається актуальною для України, як і багатьох країн колишнього СРСР і в XXI ст.

\section{Література:}

1. Книш 3. За смілий погляд на дійсність. Сьогодні і завтра (думки націоналіста). Вінніпег, 1950. С. 25-40.

2. Книш 3. Що буде завтра? Сьогодні і завтра (думки націоналіста). Вінніпег. 1950. С. 57-76.

3. Книш 3. До проблем тривожного майбутнього. СУ. 1950. № 4 (27). С. 16-22, № 5(28). С. 10-13.

4. Книш 3. Без ілюзій. СУ. 1957. № 1(97). С. 7-10.

5. Андрієвський Д. Перспективи укладу світових сил та українська міжнародна акція. Самостійна Україна. 1955. № 9(89). С. 2-6; 1965. № 11-13(90-91). С. 12-15.

6. Андрієвський Д. Що діється в Україні. Самостійна Украӥна. 1963. № 6(172). С. 2-8.

7. Бойдуник О. Сучасний стан визвольної політики. Париж, 1965. 22 с.

8. Бойдуник О. В поклоні світлому минулому - змагаймо до перемоги в майбутньому. СУ. 1965. № 3(193). С. $2-6$.

9. Гайвас Я. Перспективи української визвольної боротьби і роля української спільноти в світі. СУ. 1963. № 10(176), № 11(177). С. 40-55.

10. Гайвас Я. На порозі нового. Париж, 1968. 16 с. 